\title{
Tactical Dashboard Design for Study Program in University
}

\author{
Erna Piantari ${ }^{1}$, Rani Megasari ${ }^{2}$, Kevin Adriansyah Hidayat $^{3}$ \\ \{erna.piantari@upi.edu', megasari@upi.edu ${ }^{2}$ \} \\ Departemen Pendidikan Ilmu Komputer, Universitas Pendidikan Indonesia ${ }^{1,2,3}$
}

\begin{abstract}
University is a non-profit organization which consists of several unit organization. In Indonesia, the smallest unit organization of university is a study program that serves the citizens by specific education. The Indonesia government monitors all the study programs by some indicators that represent its performance. Dashboard is a system that holds all information so that the organization can use the information to monitor the organization's performance. The dashboard can be categorized based on a managerial level, one of them is a tactical dashboard. Therefore, in this study, a tactical dashboard was designed to present information on the program study at university.
\end{abstract}

Keywords: Tactical dashboard, Managerial dashboard, Key performance indicators

\section{Introduction}

Dashboard is a system that was developed to provide information that can be used as an organization overview [1]. In general, the use of dashboards is divided into 3 levels, namely strategic dashboards, tactical dashboards, and operational dashboards [1]. The difference between three dashboards is the scope of information presented and the user level of managerial. A strategic dashboard is a dashboard that is used to monitor the implementation of organizational strategy [2] in a longer period. While the tactical dashboard is a dashboard used to monitor the managerial activities of a department or a project [3] [4] with a medium-term and the information displayed in more detail. The information displayed on the tactical dashboard is used by managers to analyze the results of business process activities in a department [3]. Another dashboard is an operational dashboard. This dashboard is used by staff or administrators to monitor operational activities [2]. The operational dashboard displays information in realtime [5].

For each dashboard, development is a challenge. Many dashboards that have been built cannot have a significant impact on the organization. This is because the purpose of the dashboard development is often not achieved. There are several things that must be considered when building a dashboard. Firstly, the purpose of developing the dashboard must be adjusted to the managerial level of users who will use it [6]. In other words, for the same organization and information, it is possible to build different dashboards if the users are different. Another thing that needs to be considered when building a dashboard is the visualization feature used to present data. The determination of this feature depends on the information you want to display and the type of data that compiles the information [6]. 
The study program as the smallest organizational unit at the University manages information related to the management of learning at the University. To help the management of study program management, a dashboard that is able to display information needed by managerial is needed. The main propose of this research is to build a tactical dashboard that matches the characteristics and business processes of the study program. In this study, we design a KPI methodology analysis assessment to build a tactical dashboard that is able to explore all the detailed information that must be displayed on the dashboard. Therefore our contribution in this paper is:

1. A tactical dashboard design for a study program in University

2. Information and KPI (Key Performance Index) that should be delivered in the study program tactical dashboard

3. A methodology using analysis KPI assessment for developing a tactical dashboard

\section{Literature Review}

\subsection{Dashboard}

Dashboard is an application that was built with the aim to monitor the organization's performance and as a measurement system to achieve the desired targets in accordance with KPI so that data and information can be managed and presented effectively and efficiently. Dashboard facilitates the organization in assessing, adjusting and perfecting strategies to optimize its performance. In [7] that dashboard provides three main benefits:

1. Communicating a strategy. Dashboards are used to communicate strategies and goals made by the executive to all interested parties, according to their roles and levels in the organization.

2. Monitor and adjust strategy implementation. Dashboards are used to monitor the implementation of plans and strategies that have been made. Dashboards allow executives to identify critical issues and develop strategies to address them.

3. Delivering insights and information to all parties. The dashboard presents information at a glance using graphics, symbols, charts and colors that make it easy for users to understand and perceive information correctly.

\section{Methodology}

The research methodology that we used in this paper is consists of seven steps. This methodology will focus on how the right information can deliver correctly. For that purpose, the methodology will there be some assessment activities done to identify the organization KPI. Figure 1 shows the methodology that we did in this research. Each step was explained in the next section. 


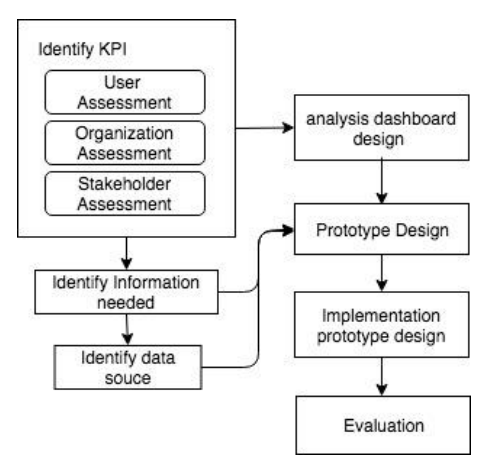

Fig. 1. Research Methodology.

\subsection{Identify KPIs (Key Performance Index)}

For developing a tactical dashboard, the KPIs identification process is very important. The developer must ensure that the information which will be showed in the dashboard is information needed based on the right KPIs of the organization. In this research, we identified the KPIs by three processes i.e user assessment, organization assessment and stakeholder assessment.

User Assessment is a stage that carried out to identify a user who uses the information that will be presented on the dashboard. This process is very important because it determines the main propose of dashboard development.

Organization Assessment conducted to determine the characteristics and business processes of the organization. In accordance with the theoretical study in Section 2, the dashboard can be defined as a method used to visualize data obtained from activities that occur within an organization. Therefore, in designing a dashboard, it is very important to know the activities and business processes of an organization.

Stakeholder Assessment conducted to identify the parties interested in the organization. Of the several stakeholders involved in the business process of the organization, it is necessary to identify the stakeholders who most often use data sourced from the organization.

\subsection{Identify Information and Data Source}

Information identification is the next process that is carried out after KPI identification. This information will be useful for designing dashboard layouts and visualization of each KPI. After identifying information, the next step is data source identification. Data source identification is needed to design the backend of the dashboard, which designs the database or warehouse architecture.

\subsection{Analyst Dashboard Design}

The dashboard design process consists of 2 designs, namely frontend design, and backend design. Frontend design on the dashboard is a design that focuses on the purpose of displaying 
the data as well as possible so that the information displayed can represent the condition of the organization and can be used by users according to their needs. Whereas design backend focuses on how to design dashboards and databases so that, the need to display data can be realized and the computational performance of the application being built will run well.

\section{Result and Discussion}

\subsection{Key Performace Indicators (KPI)}

User Assessment result. Users who will use the Study Program dashboard at a University study program managerial team in the study program. In this research, we used the Computer Science study program as our case, and here we found there were 3 main managerial study programs e.i Study Program Chair, Department Chair and Department Secretary. Managerial Study Program is the main user who will use the dashboard. The managerial study program is concerned to monitor the achievement of strategies that have been designed. The strategy is based on the Vision and Mission of the Organization. The achievement of the strategy from the vision and mission will then become a Key Performance Indicator that must be monitored and presented on the dashboard.

Organization assessment result. Refers to business process university WU in ITB as a sample model of business process and interviewed the management of Computer Science Departement in UPI, in this research, the business process of study program of Computer Science UPI was formulated and presented in Figure 2.

From the business process illustrated in Figure 2, the resources needed by the study program to run the business process are divided into four main sources:

1. Teacher

2. Facility and infrastructure

3. ICT, stakeholder, government roles (Ristekdikti)

4. Education Program

The three resources of four resources can be provided and determined independently by the study program, while the resources related to government policy have been determined by the government and the study program is only execute the predetermined program. Therefore, the resources which determine the performance of study programs are only teacher resources, facilities and education programs. From the results of the assessment conducted the implementation and implementation of the education program is still under the managerial of the study program.

While in the main process, there are three main business processes in the study program are education, research and development, and community services. Education is a process with which the main object is students. The quality of education activities can be reflected in student performance in the education or learning process.

Two other main processes are research and community services. Both of these processes are closely related to teacher performance because although all parties in a study program are responsible for this process, the teacher is still the main actor in research and community services activities, this is also in accordance with the task of lectures in Indonesia in doing Tridarma, therefore both of these activities represent the performance teacher. 


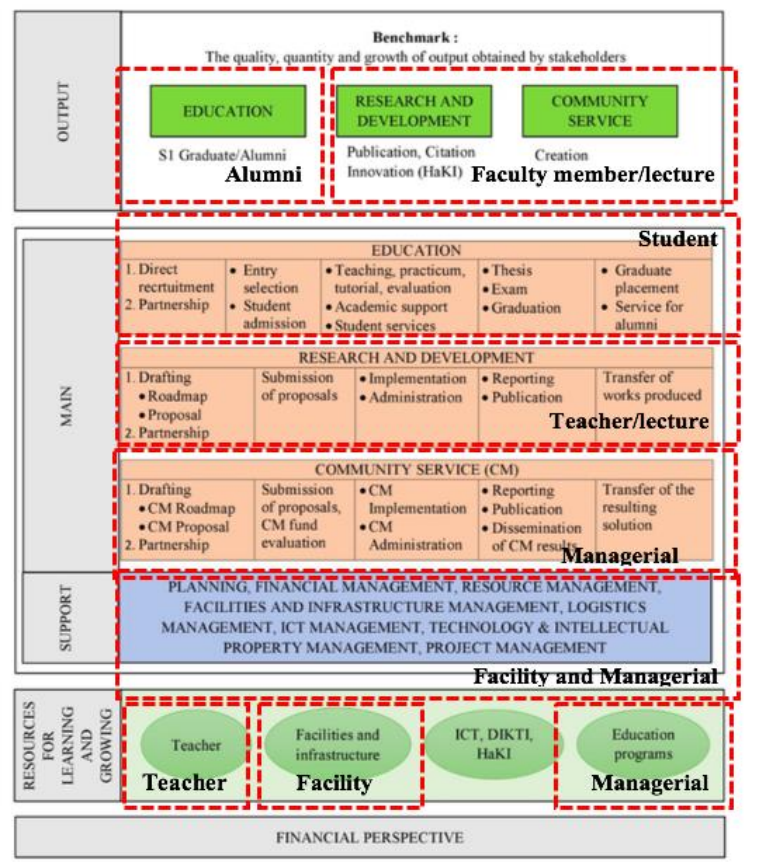

Fig. 2. Business process of computer science UPI study program.

In addition to the main processes, there are supporting processes, namely managerial activities i.e planning, financial management, infrastructure management, and other management activities. Managerial activity is very influential on how the performance of a study program.

In Figure 2, it is explained that the output of the business process of the study program is alumni and the results of research activities and community services activities. What needs to be monitored is the results of these outcomes. Obviously, the outcome information can be seen from how the alumni performance produced in the community and the world of work. While the outcome of research and community service cannot be separated from the performance of the teacher.

From the results of the business process analysis, in Figure 2, it can be identified five elements contained in the study program that must be able to represent the performance of the study program. These elements are teacher, student, facility, management, and alumni. These elements will be the focus of the dashboard information that is displayed. Performance information from these elements is part of the information that represents the study program's performance.

Stakeholder assessment result. For Higher Education organizations, Kemenristekdikti (Ministry of Research, Technology and Higher Education of the Republic of Indonesia) is a supervisory and policy-setting institution of Higher Education quality standards in Indonesia. So in this assessment process, we more focused on how Menristekdikti plays a role in the Study Program business process, and what data is often used by Menristekdikti. In its role, Menristekdikti has compiled a tool that is used to collect data from a study program to support its task of supervising the quality of Higher Education in Indonesia. The tool is called Borang. 
From the user assessment, organization assessment and stakeholder assessment processes, it can be identified the source of the formulation of the Key Performance Index that is used to design a dashboard. The sources of formulation were obtained to identify KPIs for study programs are:

a. Vision, mission and strategy of study program that has been formulated in Table 1.

Table 1. Mission and strategy of computer science study program at UPI.

\begin{tabular}{|c|c|c|c|}
\hline Mission & Strategy & Code & Element \\
\hline \multirow[t]{2}{*}{$\begin{array}{l}\text { Mission 1: Carry out quality and } \\
\text { professional education and develop } \\
\text { computer science disciplines in accordance } \\
\text { with stakeholder demands. }\end{array}$} & $\begin{array}{l}\text { Organize lecture activities in accordance with ISO 9001: } \\
2015 \text { standards } \\
\text { Increase the percentage of lecturers giving lectures with } \\
\text { subject based on research results }\end{array}$ & ST01 & \multirow[t]{2}{*}{$\begin{array}{l}\text { Lecturer, } \\
\text { Student, } \\
\text { Managerial } \\
\text { (facility) }\end{array}$} \\
\hline & $\begin{array}{l}\text { Improve lecturer qualifications } \\
\text { Increase the number of lecturers attending further study } \\
\text { education }\end{array}$ & $\begin{array}{l}\text { ST03 } \\
\text { ST04 }\end{array}$ & \\
\hline \multirow[t]{2}{*}{$\begin{array}{l}\text { Mission 2: Carry out innovative and } \\
\text { creative research by considering the } \\
\text { following aspects: local wisdom, cross- } \\
\text { fertilization with education and } \\
\text { multidisciplinary fields to contribute to the } \\
\text { ASEAN level. }\end{array}$} & $\begin{array}{l}\text { Increase the percentage of lecturers who receive research } \\
\text { grants at the local and national levels in accordance with } \\
\text { ISO 9001: } 2018 \\
\text { Increasing the number of lecturers' publications / } \\
\text { scientific works at national and international levels } \\
\text { Increase the number of lecturer products that obtain Hak }\end{array}$ & ST06 & \multirow[t]{2}{*}{$\begin{array}{l}\text { Lecturer, } \\
\text { Student }\end{array}$} \\
\hline & Kekayaan Intelektual (HKI) & & \\
\hline \multirow{4}{*}{$\begin{array}{l}\text { Mission 3: To socialize and apply } \\
\text { innovative and creative research } \\
\text { experiences and results in the field of } \\
\text { computer science for the benefit of } \\
\text { stakeholders }\end{array}$} & $\begin{array}{l}\text { Increase the percentage of lecturer participation in } \\
\text { community service activities }\end{array}$ & ST08 & \multirow[t]{4}{*}{$\begin{array}{l}\text { Lecturer, } \\
\text { Student }\end{array}$} \\
\hline & $\begin{array}{l}\text { Increase the number of lecturers involved or participate in } \\
\text { international level activities }\end{array}$ & ST09 & \\
\hline & $\begin{array}{l}\text { Increase the number of journals published by computer } \\
\text { science study programs }\end{array}$ & ST10 & \\
\hline & The amount of research utilized by the community & ST11 & \\
\hline \multirow{4}{*}{$\begin{array}{l}\text { Mission 4: Manage Study Programs, } \\
\text { strengthen networks and partnerships with } \\
\text { professional institutions and institutions, as } \\
\text { well as improve the quality of human } \\
\text { resources with global competitiveness in the } \\
\text { National and ASEAN scope. }\end{array}$} & $\begin{array}{l}\text { Increase the amount of cooperation with other institutions } \\
\text { Increasing the number of human resources who increased } \\
\text { his career }\end{array}$ & $\begin{array}{l}\text { ST12 } \\
\text { ST13 }\end{array}$ & \multirow[t]{4}{*}{$\begin{array}{l}\text { Managerial, } \\
\text { Alumni }\end{array}$} \\
\hline & Increase the number of competent certified graduates & ST14 & \\
\hline & Increase the number of graduates who got a job quickly & ST15 & \\
\hline & Increase the average graduate GPA & ST16 & \\
\hline
\end{tabular}

b. Borang of study program by Ristedikti in Table 2

Table 2. Borang of study program.

\begin{tabular}{lll}
\hline Standart & Code & Element \\
\hline Vision, Mission, Objectives, and Strategy & A19-01 & Managerial \\
Governance and Cooperation & A19-02 & Managerial \\
Student & A19-03 & Student \\
Human Resources & A19-04 & Lecturer, Educational Staff \\
Finance, Facilities, and Infrastructure & A19-05 & Managerial \\
Education & A19-06 & Students, Lecturers, Alumni \\
Research & A19-07 & Lecturer, Student \\
Community service & A19-08 & Lecturer, Student \\
Tridharma's Outcomes and Achievements & A19-09 & Managerial \\
\hline
\end{tabular}

From the results of the analysis, the study program's KPI is formulated as follows (Table 3) : 
Table 3. KPIs of Computer Science Study Program in UPI.

\begin{tabular}{|c|c|c|c|}
\hline No & Key Performance Indicators (KPI) & Source & Element \\
\hline 1 & Ratio of prospective students : capacity & ST01, A08-03, A19-03, SD18 & Student \\
\hline 2 & $\begin{array}{l}\text { Ratio of regular new students who register: applicant } \\
\text { students who pass the selection }\end{array}$ & ST01, A08-03, A19-03, SD18 & Student \\
\hline 3 & Percentage of students who dropped out or resigned & ST01, A08-03, A19-03, SD18 & Student \\
\hline 4 & Percentage of students who graduate on time & ST14, A08-03, A19-03, SD18 & Student \\
\hline 5 & Student achievements in the areas of talent and interest & ST01, A08-03, A19-03, SD01 & Student \\
\hline 6 & $\begin{array}{l}\text { Average Grade Point Average (GPA) for the past five } \\
\text { years }\end{array}$ & ST16, A08-03, A19-03, SD01 & Student \\
\hline 7 & Average thesis completion time & ST01, A08-03, A19-03, SD18 & Student \\
\hline 9 & Quality of service to students for each type of service & ST01, A08-06, A019-05, SD02 & Facility \\
\hline 10 & Tracking of graduate data & $\begin{array}{l}\text { ST14, ST15, ST16, A08-03, A19- } \\
06, \text { SD03 }\end{array}$ & Alumni \\
\hline 11 & Use of tracking results for improvements & $\begin{array}{l}\text { ST14, ST15, ST16, A08-03, A19- } \\
06, \text { SD03 }\end{array}$ & Managerial \\
\hline 12 & The company's opinion on the quality of alumni & $\begin{array}{l}\text { ST14, ST15, A08-03, A19-06, } \\
\text { SD03 }\end{array}$ & Alumni \\
\hline 13 & Waiting period for work & ST15, A08-03, A19-06, SD03 & Alumni \\
\hline 14 & $\begin{array}{l}\text { The suitability of the field of work with the field of } \\
\text { study }\end{array}$ & ST15, A08-03, A19-06, SD03 & Alumni \\
\hline 15 & $\begin{array}{l}\text { Participation of alumni in supporting the academic } \\
\text { development of study programs }\end{array}$ & ST12, A08-03, A19-06, SD03 & Alumni \\
\hline 16 & $\begin{array}{l}\text { Participation of graduates and alumni in supporting the } \\
\text { development of non-academic study programs }\end{array}$ & A08-03, A19-06, SD03 & Alumni \\
\hline 17 & Operational guidelines & ST01, A08-05, A19-02, SD05 & Managerial \\
\hline 18 & $\begin{array}{l}\text { Availability of guidelines, socialization, and use of } \\
\text { thesis guidance }\end{array}$ & ST01, A08-04, A19-04, SD05 & Managerial \\
\hline 19 & Fulltime Teaching Equivalent & ST01, A08-04, A19-04, SD04 & Teacher \\
\hline 20 & The level of attendance of lecturers in teaching & ST01, A08-04, A19-04, SD06 & Teacher \\
\hline 21 & Achievements in awarding grants & ST05, A08-07, A19-07, SD06 & Teacher \\
\hline 22 & Development of intellectual behavior & ST03, A08-07, A19-07, SD04 & Teacher \\
\hline 23 & Lecturer Education & ST03, A08-04, A19-04, SD07 & Teacher \\
\hline 24 & Educator Certificate & ST03, A08-04, A19-04, SD07 & Teacher \\
\hline 25 & $\begin{array}{l}\text { The reputation and breadth of lecturer networks in the } \\
\text { academic and professional fields }\end{array}$ & $\begin{array}{l}\text { ST03, A08-04, A19-04, SD11, } \\
\text { SD04 }\end{array}$ & Teacher \\
\hline 26 & Expert activity & $\begin{array}{l}\text { ST03, ST06, A08-04, A19-04, } \\
\text { SD04 }\end{array}$ & Managerial \\
\hline 27 & increasing the ability of lecturers & ST03, A08-04, A19-04, SD04 & Teacher \\
\hline 28 & Efforts to improve the learning system & ST01, A08-02, A19-02, SD04 & Managerial \\
\hline 29 & Librarian and its qualifications & ST01, A08-04, A19-04 & Educational Staff \\
\hline 30 & $\begin{array}{l}\text { Laboratory assistants, technicians, operators, } \\
\text { programmers }\end{array}$ & ST01, A08-04, A19-04 & Educational Staff \\
\hline 31 & Number of administrative staff & ST01, A08-04, A19-04 & Educational Staff \\
\hline 32 & Completeness and formulation of competencies & ST01, A08-02, A19-02, SD05 & Managerial \\
\hline 33 & Orientation and conformity with vision and mission & ST01, A08-01, A19-01, SD05 & Managerial \\
\hline 34 & Conduct curriculum review & ST01, A08-02, A19-02, SD04 & Managerial \\
\hline 35 & $\begin{array}{l}\text { Adjustment of curriculum with the development of } \\
\text { science and technology }\end{array}$ & ST01, A08-02, A19-02, SD05 & Managerial \\
\hline 36 & $\begin{array}{l}\text { The suitability of the course and its sequence with the } \\
\text { competency standards }\end{array}$ & ST01, A08-02, A19-02, SD05 & Managerial \\
\hline 37 & $\begin{array}{l}\text { The courses are equipped with course descriptions, } \\
\text { syllabi, and SAP }\end{array}$ & ST01, A08-05, A19-06, SD12 & Teacher \\
\hline 38 & $\begin{array}{l}\text { The substance of practicum and practicum } \\
\text { implementation }\end{array}$ & $\begin{array}{l}\text { ST01, A08-05, A19-06, SD13, } \\
\text { SD12 }\end{array}$ & Student \\
\hline 39 & The mechanism of preparing lecture material & ST01, A08-05, A19-06, SD12 & Teacher \\
\hline 40 & Quality of exam questions & ST01, A08-05, A19-06, SD12 & Teacher \\
\hline 41 & Average number of students per Academic Mentor & ST01, A08-05, A19-06, SD12 & Teacher \\
\hline 42 & Implementation of academic coaching activities & $\begin{array}{l}\text { ST01, A08-05, A19-06, SD10, } \\
\text { SD16 }\end{array}$ & Teacher \\
\hline 43 & Effectiveness of trusteeship activities & ST01, A08-05, A19-06, SD16 & Teacher \\
\hline 44 & Academic interaction & $\begin{array}{l}\text { ST01, A08-05, A19-06, SD16, } \\
\text { SD04 }\end{array}$ & Managerial \\
\hline
\end{tabular}




\subsection{Dashboard Design and The Prototype}

In this paper, we focus on frontend design, which is the problem in this design is how data and information will be displayed on the dashboard. According to the previous discussion, there are two things that should be done when doing this design. The first is how the dashboard layout settings will be presented and the second is how visual the information. From the results of the previous assessment, there are five main elements of the study program were produced. These five elements will be the basis for designing the dashboard layout. So that, generally there will be five dashboards on the study program tactical dashboard. However, it should be designed as a dashboard as a summary of the study program's performance. This section will be present the dashboard design.

Summary dashboard. The summary dashboard is designed to show overall information about the organization, in this case, the Computer Science study program of UPI. According to the analysis result, there are five elements that construct the study program as a whole. Therefor in the summary dashboard will present that five elements. Gauge chart is used to visualize the performance of each element and heat map chat is used to visualize the performance of each KPIs as a whole. Figure 3 shows the prototype of this dashboard.

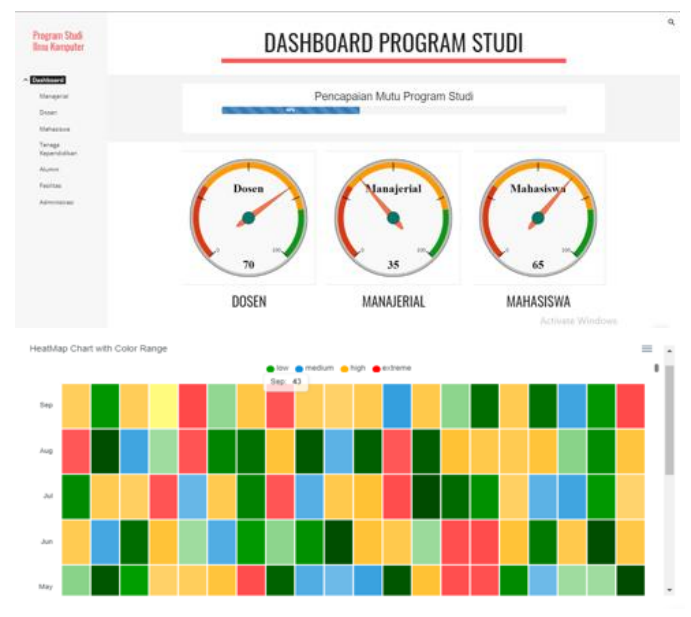

Fig. 3. Summary Dashboard Prototype.

Detail Information of Tactical Dashboard. The tactical dashboard should present the detail of the organization's information. The detail of the organization information is presented as KPI of the organization. These KPI would be visual a graphic or any other visualization technique. The visualization technique used to representation the KPI for each dashboard was done by considering the information that going to deliver and the data form. In another research, we define a taxonomy of visualization technique that used to decide how the KPI would be visualized in Figure 4. 


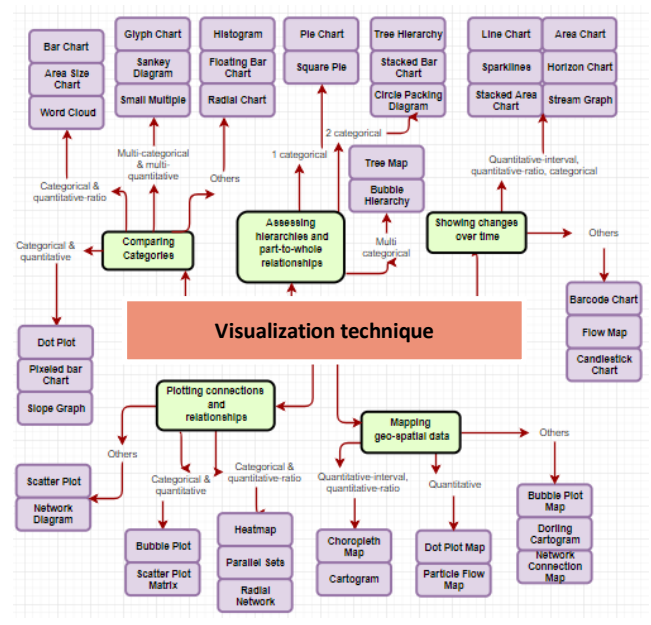

Fig. 4. Visualization technique

According to Table 3, there are 64 KPIs in the Study Program. Each KPI belongs to the study program's element that has been defined. Therefore in this paper, it was designed a detailed dashboard for each element. The teacher dashboard in Figure 5 (Dosen in Indonesian language) was displayed KPI relating to teachers, such as teacher qualifications and teacher performance that is presented by research and services community activities (Table 3 ). This is also the same for the Student dashboard in Figure 6.
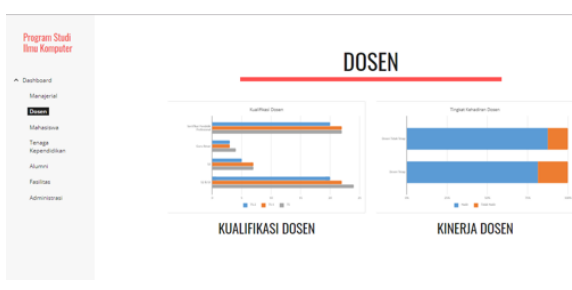

Fig. 5. Tactical Teacher Dashboard.
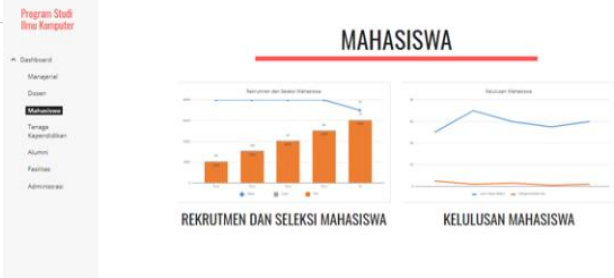

Fig. 6. Tactical Students Dashboard

\section{Conclusion}

In this paper, we designed a tactical dashboard for University study programs. In developing a dashboard, the most important thing was presenting the right information correctly. To support this, the tactical dashboard development process was carried out by starting with the identification of organizational KPIs. The organizational KPI identification process was carried out with several assessment processes (users, organizations, and stakeholders). The main user of the study program dashboard is the study program managerial team. The study program has the characteristics of business processes that are different from other organizations. From the results of the business process analysis, there are 5 elements that support the business process of the study program i.e: student, teacher, managerial, facility and alumni. 
In addition, Menristekdikti is a stakeholder who has the most important role in the study program business process activities. Menristekdikti plays in monitoring and evaluating the quality of study programs. It arranged Borang as a tool for evaluating. Therefore, by the analysis of the vision and mission, the organization's business processes, and stakeholder interests, there are 64 KPIs of study programs that were obtained. Then the dashboard design process was done by visualizing the information. This process consists of two parts process: first, building a dashboard layout and second, of visualizing information from each KPI. Layout development was carried out by dividing the tactical dashboard into one dashboard summary and five detail dashboards which were developed based on the elements defined from the results of the analysis that was conducted at UPI's Computer Science Study Program. The visualization process of each KPI is done by considering the information that has been delivered and the form of data that conducts the information.

Acknowledgments. This work was supported by the Ministry of Research, Technology and Higher Education of the Republic of Indonesia.

\section{References}

[1] Rahman, A. A., Adamu, Y. B., \& Harun, P.: Review on dashboard application from managerial perspective. International Conference on Research and Innovation in Information Systems (ICRIIS), pp. 1-5. IEEE. (2017)

[2] Eckerson, W. W.: Performance dashboard: Measuring, Monitoring and managing your business. Bussiness p, 321. (2011)

[3] Dragomeriscu, S.E., \& Solomon, D.C.: The Role of the Performance Dashboard. Stud, sci.res., vol. Economics, no 10, pp 166-176 (2013)

[4] Gaur, P., \& Arora, M. : CRM Dashboard for square Yards: An application of business analytics. Vol 6 February. pp. 1-11 (2016)

[5] Kim, J., Jo, I. H., \& Park, Y.: Effect of learning analytics dashboard: Analysing the relations among dashboard utilization, satisfaction, and learning achievement. Asia Pacific Educ. Rev., vol 17 no 1, pp. 13-24. (2016)

[6] Yigitbasioglu, O. M., \& Velcu, O.: A review of dashboards in performance management: Implications for design and research. International Journal of Accounting Information Systems, 13(1), pp. 41-59 (2012)

[7] Gonzalez, T. Dashboard Design: Key Performance Indicators \& Metrics.Brighpoint Consulting, Inc, Indianapolis (2005) 